\title{
Candida digboiensis sp. nov., a novel anamorphic yeast species from an acidic tar sludge-contaminated oilfield
}

Correspondence

G. S. Prasad prasad@imtech.res.in

\author{
G. S. Prasad, ${ }^{1}$ S. Mayilraj, ${ }^{1}$ Nitu Sood, ${ }^{2}$ Vijeyta Singh, ${ }^{2}$ Kakoli Biswas ${ }^{1}$ \\ and Banwari Lal ${ }^{3}$
}
${ }^{1}$ Microbial Type Culture Collection and Gene Bank (MTCC), Institute of Microbial Technology (IMTECH), Council of Scientific and Industrial Research (CSIR), Sector 39A, Chandigarh 160036, India

${ }^{2}$ TERI School of Advanced Studies, The Energy and Resources Institute (TERI), Darbari Seth Block, India Habitat Centre, Lodhi Road, New Delhi 110003, India

${ }^{3}$ TERI, Darbari Seth Block, India Habitat Centre, Lodhi Road, New Delhi 110003, India
During a research programme isolating bacteria from acidic tar sludge-contaminated soils, two yeast strains (TERI- $6^{\mathrm{T}}$ and TERI-7) belonging to the genus Candida were isolated from such a soil $(\mathrm{pH} 2 \cdot 0)$ collected from the Digboi oil refinery in Assam, a state in the north-eastern part of India $\left(27 \cdot 33^{\circ} \mathrm{N} 95 \cdot 40^{\circ} \mathrm{E}\right)$. These two isolates were obtained on the nutrient agar plates used for isolating bacteria from the sludge-contaminated soil of an oilfield. Small colonies appeared on that medium and were sent for characterization to the Microbial Type Culture Collection and Gene Bank (MTCC), Chandigarh, India. There are very few reports on the isolation of yeast species from this habitat: yeast

Published online ahead of print on 29 October 2004 as DOI 10.1099/ ijs.0.63313-0.

Abbreviations: ITS, internal transcribed spacer; SSU, small subunit.

The GenBank/EMBL/DDBJ accession numbers for the 26S rRNA gene D1/D2 domain, ITS and 18S rRNA gene sequences of strains MTCC $4371^{\top}$ and MTCC 4372 are respectively AJ549212 and AJ549213, AJ697745 and AJ697746, and AJ697749 and AJ697750, and the accession numbers for the ITS sequences of $C$. blankii MTCC $1442^{\top}$ and MTCC 624 are AJ697747 and AJ697748. strains have been isolated from oilfields and oil brines in Japan (Iizuka \& Goto, 1965; Iizuka \& Komagata, 1965). Recently, Candida bituminiphila from tar was reported (Robert et al., 2001). On the basis of conventional morphological and physiological tests, the strains were shown to be related to Candida blankii and Zygoascus hellenicus, though they differed from them in several physiological tests. No sexual reproduction was observed on corn meal agar (HiMedia), malt agar, Gorodkowa agar (Yarrow, 1998), YM agar (HiMedia) or V8 agar (Difco). Sequence analysis of rRNA genes also showed that the strains are closely related to C. blankii. All these data supported the assignment of strain TERI- $6^{\mathrm{T}}$ to a novel species, for which we propose the name Candida digboiensis.

The yeast strains examined in this study are listed in Table 1 and are available from the MTCC, the Centraalbureau voor Schimmelcultures (CBS), Utrecht, The Netherlands, and the Japan Collection of Microorganisms (JCM), Wakoshi, Japan. All the strains were grown on YM agar at $25^{\circ} \mathrm{C}$. Phenotypic characteristics were examined using standard methods for yeast taxonomy (Yarrow, 1998). 
Table 1. Strains used in this study

\begin{tabular}{|c|c|c|c|}
\hline Strain & Substrate & Location & ITS accession no. \\
\hline $\begin{array}{l}\text { C. digboiensis sp. nov. TERI-6 }{ }^{\mathrm{T}}\left(=\text { MTCC } 4371^{\mathrm{T}}\right. \\
\left.=\mathrm{CBS} 9800^{\mathrm{T}}=\mathrm{JCM} 12300^{\mathrm{T}}\right)\end{array}$ & Acid tar sludge-contaminated soil & Digboi, Assam, India & AJ697745 \\
\hline C. blankii MTCC $1442^{\mathrm{T}}\left(=\mathrm{CBS} 1898^{\mathrm{T}}\right)$ & Blood of mink (Putorius vison) & Canada & AJ697747 \\
\hline
\end{tabular}

*Type strain of C. hydrocarbofumarica.

The yeast strains were grown in YM broth (HiMedia) for $24 \mathrm{~h}$ at $25^{\circ} \mathrm{C}$, harvested by centrifugation, resuspended in sterile $1 \mathrm{M}$ sorbitol and transferred to $1.5 \mathrm{ml}$ microfuge tubes. The cell pellet was used for DNA isolation with the MasterPure Yeast DNA purification kit (Epicentre Technologies) according to the manufacturer's instructions.

Each PCR was performed in a final reaction mixture $(50 \mu \mathrm{l})$ containing $50 \mathrm{ng}$ genomic DNA, 25 pmol each primer, $200 \mathrm{mM}$ each of dATP, dTTP, dGTP and dCTP (Promega), $2 \cdot 5 \mathrm{mM} \mathrm{MgCl}_{2}, 2 \cdot 0 \mathrm{U}$ Taq polymerase (Promega) and $5 \mu \mathrm{l}$ $10 \times$ reaction buffer (Promega). Primers ITS1 and ITS4 were used to amplify the internal transcribed spacer (ITS) region, while NS1 and NS8 were used for amplifying the small-subunit (SSU) rRNA gene (White et al., 1990). The D1/D2 domain of the large-subunit rRNA gene was amplified with primers NL1 and NL4 (Kurtzman \& Robnett, 1998). The primers were obtained from Integrated DNA Technologies. Amplification reactions were performed in a PTC 150 Mini Cycler (MJ Research) with the following cycling parameters: initial denaturation for $5 \mathrm{~min}$ at $94^{\circ} \mathrm{C}$, followed by 30 cycles of $30 \mathrm{~s}$ at $94^{\circ} \mathrm{C}, 30 \mathrm{~s}$ at $55^{\circ} \mathrm{C}$ and $1.0 \mathrm{~min}$ at $72{ }^{\circ} \mathrm{C}$ (for ITS and $\mathrm{D} 1 / \mathrm{D} 2$ regions) or $2.0 \mathrm{~min}$ (for SSU rRNA gene), with a final extension for $10 \mathrm{~min}$ at $72{ }^{\circ} \mathrm{C}$, and cooled to $4{ }^{\circ} \mathrm{C}$. The amplified products were separated on $1.2 \%$ agarose (Sisco Research Laboratories) gel by electrophoresis and visualized by staining with ethidium bromide $\left(0.5 \mu \mathrm{g} \mathrm{ml}^{-1}\right)$.

The amplicons were purified using the Qiagen gel extraction kit. Direct sequencing of gel-purified PCR products was performed with the ABI BigDye Terminator cycle sequencing ready reaction kit (Applied Biosystems). Both strands of the PCR product were sequenced. The SSU rRNA gene was sequenced with primers NS1-NS8, the ITS region with primers ITS1 and ITS4 (White et al., 1990) and the D1/D2 domain with primers NL1 and NL4 (Kurtzman \& Robnett, 1998). Sequencing reactions were purified by ethanol and sodium acetate precipitation. The pellet was washed twice with $70 \%$ ethanol, which considerably improved the removal of dye terminators from the reaction. Processing of the samples for loading onto an ABI 310 model sequencer was performed according to the instructions of the manufacturer (Applied Biosystems).

A sequence-similarity search was done using GenBank
BLASTN (Altschul et al., 1997). Sequences of closely related taxa were retrieved and aligned using the CLUSTAL X program (Thompson et al., 1997). For the neighbour-joining analysis (Saitou \& Nei, 1987), distances between the sequences were calculated using Kimura's two-parameter model (Kimura, 1980). Bootstrap analysis was performed to assess the confidence limits of the branching (Felsenstein, 1985).

\section{Latin diagnosis of Candida digboiensis G. S. Prasad, Mayilraj, Sood et Lal sp. nov.}

Coloniae in agaro malti humiles convexae, integrae vel fimbriatae, albae vel cremeae, butyrosae. In medio liquido cum dextroso et peptono et extracto levedinis et extracto malti post 3 dies ad $25^{\circ} \mathrm{C}$ cellulae sunt ellipsoideae ad cylindratae pro maxima partes irregulares $(2 \cdot 0-3 \cdot 5 \times 3 \cdot 0$ $9 \cdot 0 \mu \mathrm{m})$, singulae vel binae. Reproductio vegetativa per holoblastice gemmationem. In lamina Dalmau post 7 dies pseudohyphae formantur dense ramosae. Hyphae verae nonnumquam praesentes. Fermentatio nulla. Sucrosum, galactosum, L-sorbosum, D-ribosum, D-xylosum, L-arabinsum, D-arabinosum, L-rhamnosum, maltosum, trehalosum, methyl $\alpha$-D-glucosidum, cellobiosum, salicinum, melibiosum, lactosum, raffinosum (exigue), melezitosum, inulinum, erythritolum, ribitolum, xylitolum (lente), D-arabinitolum, L-arabinitolum, glucitolum, mannitolum, galactitol, myo-inositolum, glucono$\Delta$-lactonum (lente), acidum gluconicum (exigue), ethanolum, arbutinum, amylum solubile et glycerolum (lente) assimilantur, neque glucosaminum, acidum glucuronicum, acidum succinicum, acidum citricum, aut methanolum. Ethylaminum, lysinum et cadaverinum velut substrata nigrogeni utuntur, neque sodii nitratum aut nitritum. Vitaminis vel acidis aminosis absentibus haud crescit. $42^{\circ} \mathrm{C}$ crescit. In agaro calcii carbonato addito acidum non formatur. In liquido $50 \%$ glucosiii addito non crescit. $0.01 \%$ cycloheximidum non crescit. Amylum non formatur, urea non finditur, diazolium coeruleo $B$ probatio negativa. Holotypus TERI-6 ${ }^{\mathrm{T}}\left(=\right.$ MTCC $\left.4371^{\mathrm{T}}\right)$ lyophilus, isolatus e terra inquinata 'acid tar sludge', circa Digboi oil refinery, Digboi, Assam, India.

\section{Description of Candida digboiensis G. S. Prasad, Mayilraj, Sood \& Lal sp. nov.}

Candida digboiensis [dig.boi.en'sis. N.L. nom. fem. adj. digboiensis referring to Digboi $\left(27 \cdot 33^{\circ} \mathrm{N} 95 \cdot 40^{\circ} \mathrm{E}\right)$, a town 
in Assam State, north-eastern India, where the type strain was isolated].

Colonies on malt agar are low-convex, entire or fringed, white to cream and butyrous. After 3 days in YM broth at $25^{\circ} \mathrm{C}$, cells are ellipsoidal to short cylindrical $(2 \cdot 0-3 \cdot 5 \times$ $3 \cdot 0-9 \cdot 0 \mu \mathrm{m})$ and occur singly, in pairs or in short chains (Fig. 1). Some irregular shapes and a few elongated (up to $15 \mu \mathrm{m})$ cells are also present. Sympodial holoblastic conidiogenesis results in ovoid to obclavate conidia $(2-4 \mu \mathrm{m})$ that arise from pronounced protuberances. After 1 week in Dalmau plate culture, pseudohyphae consisting of branched chains of elongated cells are visible. True hyphae may be present. Fermentation absent. Sucrose, galactose, sorbose, ribose, xylose, D-arabinose, L-arabinose, L-rhamnose, maltose, trehalose, methyl $\alpha$-D-glucoside, cellobiose, salicin, melibiose, lactose, raffinose, melezitose, inulin, erythritol, ribitol, xylitol, D-arabitol, L-arabitol, D-glucitol, D-mannitol, galactitol (weak), myo-inositol, D-glucono-1,5-lactone (weak), D-glucuronate, ethanol, arbutin, starch (slow) and glycerol (weak) are assimilated. D-Gluconate, D-glucosamine, succinate, citrate and methanol are not assimilated. Ethylamine, lysine and cadaverine are utilized as sole nitrogen sources; sodium nitrate and nitrite are not. Does not grow in the absence of vitamins. Grows in the absence of amino acids. Grows at $42{ }^{\circ} \mathrm{C}$. Acid is not produced on chalk agar. Does not grow in the presence of $50 \%(\mathrm{w} / \mathrm{w})$ glucose, $0.01 \%$ $(\mathrm{w} / \mathrm{v})$ cycloheximide or $1 \%(\mathrm{v} / \mathrm{v})$ acetic acid. Does not produce starch-like compounds. Urease-negative. Diazonium blue $\mathrm{B}$ reaction is negative.
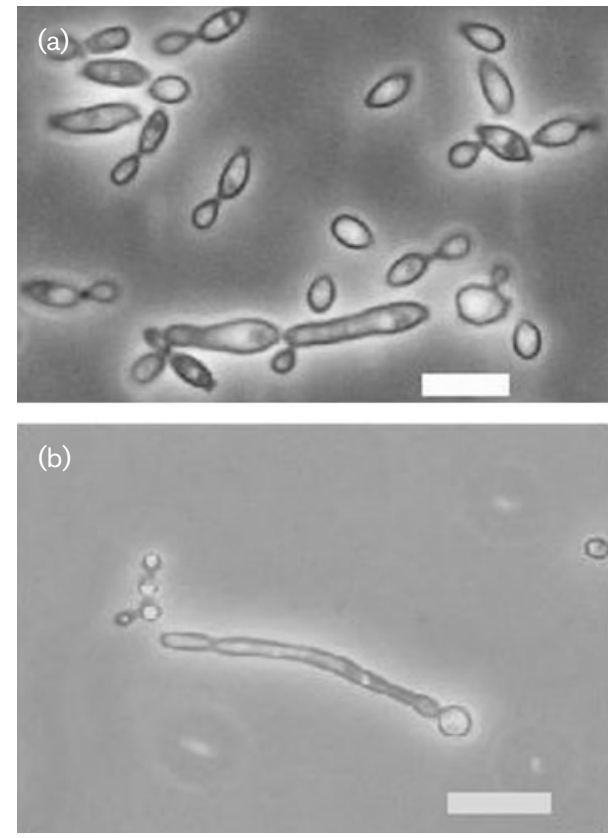

Fig. 1. (a) Vegetative cells of C. digboiensis sp. nov. MTCC $4371^{\top}$ grown in yeast nitrogen base broth (Difco) for 2 days at $25^{\circ} \mathrm{C}$. (b) Formation of pseudohyphae in YM broth after 3 days. Bars, $5 \mu \mathrm{m}$.
The type strain is strain TERI- $6^{\mathrm{T}}\left(=\right.$ MTCC $4371^{\mathrm{T}}=$ CBS $9800^{\mathrm{T}}=\mathrm{JCM} 12300^{\mathrm{T}}$ ), isolated from acid tar sludgecontaminated soil from Digboi oil refinery, Digboi, Assam, India.

\section{Physiological and phylogenetic relationships}

C. digboiensis is physiologically similar to C. blankii and less so to $Z$. hellenicus. However, compared to these two species, it shows differences in eight physiological tests. It differs from $C$. blankii in its ability to assimilate melibiose and inulin, its inability to assimilate 2-keto-D-gluconate and D-gluconate and its inability to grow at $45^{\circ} \mathrm{C}$ (two strains each of $C$. digboiensis and C. blankii were compared) and in the presence of $0.01 \%$ and $0.1 \%(\mathrm{w} / \mathrm{v})$ cycloheximide. C. digboiensis differs from Candida auringiensis and Candida salmanticensis in its ability utilize melibiose and inulin and its inability to grow in the presence of $0.01 \%$ and $0.1 \%(\mathrm{w} / \mathrm{v})$ cycloheximide. It differs from $Z$. hellenicus in its ability to assimilate melibiose, inulin, erythritol, arabitol and its inability to assimilate Dglucosamine. Z. hellenicus cannot grow at $42{ }^{\circ} \mathrm{C}$, whereas strains TERI- $6^{\mathrm{T}}$ and TERI-7 show growth at this temperature. Selected phenotypic differences between $C$. digboiensis and related species are shown in Table 2.

The variable D1/D2 domain of the large-subunit rRNA gene has been sequenced for all currently recognized ascomycetous yeasts (Kurtzman \& Robnett, 1998). These studies have shown that strains belonging to separate species generally exhibit greater than $1 \%$ sequence divergence. Strains TERI $-6^{\mathrm{T}}$ and TERI-7 show $2 \cdot 8 \%$ divergence (16 base substitutions out of $556 \mathrm{nt}$ ) from C. blankii, indicating that $C$. digboiensis could be a novel species. However, in a recent study with the yeast species Clavispora lusitaniae, it was found that the sequence variation in the D1/D2 region among mating strains of that species could exceed $6.0 \%$ (Lachance et al., 2003). At present, it is not clear whether this constitutes a rare example of polymorphism in the D1/D2 region or whether some other species are also polymorphic. For further confirmation of the novelty of the strains under study, we also sequenced the SSU rRNA gene and the ITS region (comprising ITS1, $5 \cdot 8 \mathrm{~S}$ rRNA gene and ITS2 regions) of strains TERI- $6^{\mathrm{T}}$ and TERI-7.

A BLAST search (Altschul et al., 1997) using the C. digboiensis SSU rRNA gene sequence showed that $C$. blankii is the closest relative, although most other sequences retrieved in this search were those of filamentous fungal species. A discontiguous Mega BLAST (http://www.ncbi.nlm.nih.gov/ blast/) search retrieved the yeast sequences. In the SSU rRNA gene sequence, $C$. digboiensis differs from C. blankii by 11 base substitutions and two deletions. C. salmanticensis and $C$. auringiensis are also related but show sequence divergence of $2 \cdot 3$ and $2 \cdot 7 \%$, respectively, from C. digboiensis. Most species of the Stephanoascus clade (Stephanoascus smithiae, Stephanoascus farinosus, Arxula adeninovorans, $Z$. hellenicus, C. bituminiphila etc.) show more than $5 \%$ 
Table 2. Selected characteristics of species phenotypically similar to C. digboiensis sp. nov.

Strains: 1, C. digboiensis MTCC $4371^{\mathrm{T}}$; 2, C. blankii MTCC $1442^{\mathrm{T}} ; 3$, Z. hellenicus CBS $4099^{\mathrm{T}} ; 4$, C. bituminiphila CBS $8813^{\mathrm{T}}$; 5, C. auringiensis CBS $6913^{\mathrm{T}}$; 6, C. salmanticensis CBS $5121^{\mathrm{T}}$. C. digboiensis MTCC 4372 gave identical results to $C$. digboiensis MTCC $4371^{\mathrm{T}}$ in all tests shown.

\begin{tabular}{|c|c|c|c|c|c|c|}
\hline Characteristic & 1 & 2 & 3 & 4 & 5 & 6 \\
\hline \multicolumn{7}{|l|}{ Assimilation of: } \\
\hline Melibiose & + & - & - & - & - & - \\
\hline Inulin & + & - & - & - & - & - \\
\hline 2-Keto-D-gluconate & - & + & - & - & + & $+1-$ \\
\hline D-Glucose fermentation & - & $+1-$ & + & $+1-$ & + & + \\
\hline \multicolumn{7}{|c|}{ Growth in the presence of cycloheximide at: } \\
\hline $0.01 \%(\mathrm{w} / \mathrm{v})$ & - & + & + & + & + & + \\
\hline $0 \cdot 1 \%(\mathrm{w} / \mathrm{v})$ & - & + & + & Slow & + & + \\
\hline \multicolumn{7}{|l|}{ Growth at: } \\
\hline $37^{\circ} \mathrm{C}$ & + & + & + & - & + & - \\
\hline $42^{\circ} \mathrm{C}$ & + & + & - & - & - & - \\
\hline $45^{\circ} \mathrm{C}$ & - & + & - & - & - & - \\
\hline
\end{tabular}

divergence, in the SSU rRNA gene sequence, from $C$. digboiensis, which suggests that they may be distantly related to $C$. digboiensis. Further confirmation of the novelty of C. digboiensis came from sequencing of the ITS region. As the ITS region of $C$. blankii was not available in the nucleic acid databases, we sequenced the ITS regions of two strains of C. blankii (MTCC $1442^{\mathrm{T}}$ and MTCC 624). In this region, C. digboiensis differs from C. blankii by 58 base substitutions; in addition, there are 33 base deletions in C. blankii and nine deletions in $C$. digboiensis. This strongly suggests the separation of $C$. digboiensis from C. blankii. A BLAST search with the ITS sequence of $C$. digboiensis retrieved the partial ITS sequence of C. blankii (deposited as part of this study) and only the 5.8S rRNA gene sequences of other species, the first being C. bituminiphila, followed by $Z$. hellenicus and different varieties of Zygoascus species. This again shows that the strains isolated from acidic tar sludge-contaminated soil represent a novel species.

In the phylogenetic tree constructed using the D1/D2 variable domain of the large-subunit rRNA gene (Fig. 2), C. digboiensis along with C. blankii were placed within a broad cluster comprising Stephanoascus/Arxula/Blastobotrys/ Zygoascus (the Stephanoascus clade) and some species of Candida supported by high bootstrap values (90\%). However, C. digboiensis and C. blankii appear to be more

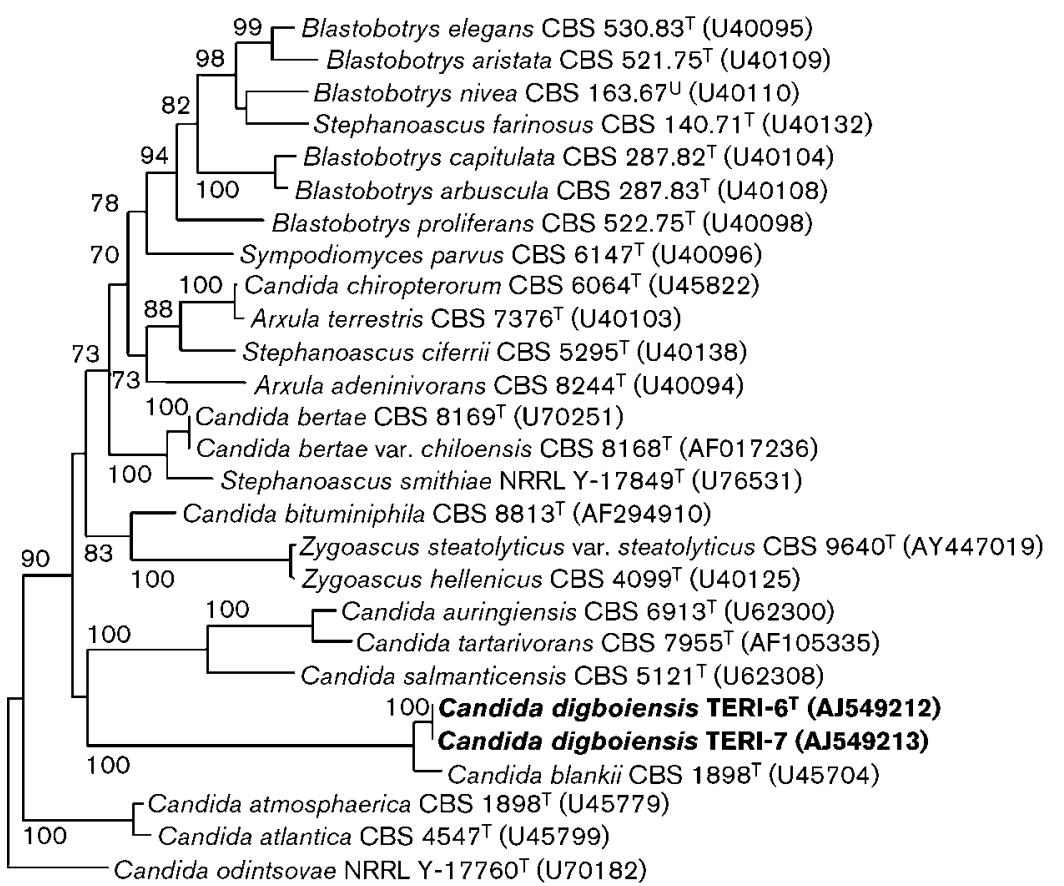

Fig. 2. Phylogenetic placement of C. digboiensis sp. nov. based on the D1/D2 variable domain sequence of the large-subunit rRNA gene. The tree was generated by NJPlot (Perrière \& Gouy, 1996). Bootstrap values (each expressed as a percentage of 1000 replications) greater than $70 \%$ are given at nodes. The scale shows $5 \%$ sequence divergence. 
closely related to $C$. auringiensis, C. salmanticensis and Candida tartarivorans than to the other species of the Stephanoascus clade. Kurtzman \& Robnett (1998) showed that C. blankii is phylogenetically distantly related to the Stephanoascus clade. Similarly, C. auringiensis, C. salmanticensis and $C$. tartarivorans appear to be only distantly related to the Stephanoascus clade (Fonseca et al., 2000). Middelhoven \& Kurtzman (2003) examined the ability of several yeast species to assimilate glycine, uric acid, n-hexadecane, putrescine and branched-chain aliphatic compounds such as isobutanol, leucine and isoleucine. Among the Saccharomycetales, most of the species belonging to the Stephanoascus clade utilized most, or all, of these compounds. C. blankii, which was considered as distantly related to the above clade, utilized n-hexadecane and five other compounds, indicating that it is physiologically more similar to members of the Stephanoascus clade. It would be interesting to examine the ability of $C$. digboiensis strains to utilize the above compounds.

Lachance \& Starmer (1998) commented that 'unfortunately too many times in the past, workers engaged in yeast isolation have not gone beyond the mere nomenclatural description of new species, failing to typify also their community, habitat, and possible interactions'. As $C$. digboiensis strains were isolated from an acid tar sludgecontaminated soil, we have investigated which other species have been isolated from hydrocarbon habitats. Although very few reports are available on the isolation of yeast species from oil-contaminated soil, yeast strains have been isolated from oilfields and oil brines in Japan (Iizuka \& Goto, 1965; Iizuka \& Komagata, 1965), and some yeast species have been reported to utilize petroleum hydrocarbons (Ismailov, 1985a, b; Palittapongarnpim et al., 1998; Radwan et al., 2001). We have examined the habitats of the closest relatives of $C$. digboiensis. Candida hydrocarbofumarica MTCC 624 (=CBS 6734), a synonym of $C$. blankii, was isolated from soil; it has been reduced to synonymy with $C$. blankii because of the high degree ( $>90 \%$ ) of nuclear DNA reassociation between the type strains of two species (Meyer et al., 1998). We have determined the sequence of the D1/D2 variable domain of the type strain of $C$. hydrocarbofumarica and found it to be identical to the sequence of the type strain of C. blankii, confirming their conspecificity. The SSU rRNA gene and ITS sequences of $C$. blankii and C. hydrocarbofumarica were also identical. C. blankii strains utilize hydrocarbons (Furukawa et al., 1970, 1978; Yamada et al., 1970). Strains of $C$. digboiensis could utilize alkane as well as aromatic fractions of acidic tar sludge (data not shown). On the basis of D1/D2 sequence analysis, C. auringiensis, C. salmanticensis and $C$. tartarivorans are the other relatives of $C$. digboiensis. Both C. auringiensis and C. salmanticensis were isolated from 'alpechin', the waste produced by olive oil extraction (Meyer et al., 1998). C. bituminiphila and $Z$. hellenicus are the other relatives of this cluster. Interestingly, C. bituminiphila was isolated from tar, which is a by-product of the crude oil industry (Robert et al., 2001).
Three strains of $Z$. hellenicus (CBS 4028, CBS 4075 and CBS 5839) have the ability to split fat (CBS web site: http:// www.cbs.knaw.nl/databases/index.htm). Yeasts are relatively rarely isolated from crude oil or hydrocarbon sources. However, phylogenetic analysis of $C$. digboiensis and related species suggests that several closely related yeast species may exist in nature. Physiological and biochemical aspects of acidic tar sludge degradation by $C$. digboiensis strains are under investigation and will be reported separately.

\section{Acknowledgements}

This study was supported by the Department of Biotechnology and the Council of Scientific and Industrial Research, Government of India (G. S. P.), and by the Indian Oil Corporation Ltd and the Department of Biotechnology, Government of India (B. L.). G. S. P. is grateful to Dr Tapan Chakrabarti for encouragement, to Mr Paramjit for his excellent technical assistance and to Dr K. W. Gams (CBS, Utrecht, The Netherlands) for help with the Latin description. This is IMTECH Communication number 24/2004.

\section{References}

Altschul, S. F., Madden, T. L., Schaffer, A. A., Zhang, J., Zhang, Z., Miller, W. \& Lipman, D. J. (1997). Gapped BLAST and PSI-BLAST: a new generation of protein database search programs. Nucleic Acids Res 25, 3389-3402.

Felsenstein, J. (1985). Confidence limits on phylogenies: an approach using the bootstrap. Evolution 39, 783-791.

Fonseca, Á., Fell, J. W., Kurtzman, C. P. \& Spencer-Martins, I. (2000). Candida tartarivorans sp. nov., an anamorphic ascomycetous yeast with the capacity to degrade $\mathrm{L}(+)$ - and meso-tartaric acid. Int J Syst Evol Microbiol 50, 389-394.

Furukawa, T., Nakahara, T. \& Yamada, K. (1970). Studies on the utilization of hydrocarbons by microorganisms. Part XIX. Influence of several factors on fumaric acid production from n-paraffin by Candida hydrocarbofumarica. Agric Biol Chem 34, 1402-1406.

Furukawa, T., Rodrigues de Miranda, L. \& Matsuyoshi, T. (1978). Fermentative production of fumaric acid from n-paraffins by Candida blankii. J Ferment Technol 56, 546-549.

lizuka, H. \& Goto, S. (1965). Microbiological studies on petroleum and natural gas. VIII. Determination of red yeasts isolated from oil brines and related materials. J Gen Appl Microbiol 11, 331-337.

lizuka, H. \& Komagata, K. (1965). Microbiological studies on petroleum and natural gas. V. Microflora of Yabase and Nishiyama oil fields in Japan. J Gen Appl Microbiol 11, 91-102.

Ismailov, N. M. (1985a). Role of yeasts of the genus Candida in the transformation of the hydrocarbon energy in oil-contaminated greybrown soil. Mikrobiologiya 54, 668-674 (in Russian).

Ismailov, N. M. (1985b). Biodegradation of petroleum hydrocarbons in soil inoculated with yeasts. Mikrobiologiya 54, 835-841 (in Russian).

Kimura, M. (1980). A simple method for estimating evolutionary rates of base substitutions through comparative studies of nucleotide sequences. J Mol Evol 16, 111-120.

Kurtzman, C. P. \& Robnett, C. J. (1998). Identification and phylogeny of ascomycetous yeasts from analysis of nuclear large subunit (26S) ribosomal DNA partial sequences. Antonie van Leeuwenhoek 73, 331-371.

Lachance, M. A. \& Starmer, W. T. (1998). Ecology and yeasts. In The Yeasts, a Taxonomic Study, 4th edn, pp. 21-30. Edited by C. P. Kurtzman \& J. W. Fell. Amsterdam: Elsevier. 
Lachance, M. A., Daniel, H. M., Meyer, W., Prasad, G. S., Gautam, S. P. \& Boundy-Mills, K. (2003). The D1/D2 domain of the largesubunit rDNA of the yeast species Clavispora lusitaniae is unusually polymorphic. FEMS Yeast Res 4, 253-258.

Meyer, S. A., Payne, R. W. \& Yarrow, D. (1998). Candida Berkhout. In The Yeasts, a Taxonomic Study, 4th edn, pp. 454-573. Edited by C. P. Kurtzman \& J. W. Fell. Amsterdam: Elsevier.

Middelhoven, W. J. \& Kurtzman, C. P. (2003). Relationship between phylogeny and physiology in some ascomycetous yeasts. Antonie van Leeuwenhoek 83, 69-74.

Palittapongarnpim, M., Pokethitiyook, P., Upatham, E. S. \& Tangbanluekal, L. (1998). Biodegradation of crude oil by soil microorganisms in the tropic. Biodegradation 9, 83-90.

Perrière, G. \& Gouy, M. (1996). WWW-query: an on-line retrieval system for biological sequence banks. Biochimie 78, 364-369.

Radwan, S. S., Al-Aawadi, H. A. \& Khanafer, M. (2001). Effects of lipids on $\mathrm{n}$-alkane attenuation in media supporting oil-utilizing microorganisms from the oily Arabian Gulf coasts. FEMS Microbiol Lett 198, 99-103.

Robert, V., Bonjean, B., Karutz, M., Paschold, H., Peeters, W. \& Wubbolts, M. G. (2001). Candida bituminiphila, a novel anamorphic species of yeast. Int J Syst Evol Microbiol 51, 2171-2176.

Saitou, N. \& Nei, M. (1987). The neighbor-joining method: a new method for reconstructing phylogenetic trees. Mol Biol Evol 4, 406-425.

Thompson, J. D., Gibson, T. J., Plewniak, F., Jeanmougin, F. \& Higgins, D. G. (1997). The CLUSTAL_X windows interface: flexible strategies for multiple sequence alignment aided by quality analysis tools. Nucleic Acids Res 25, 4876-4882.

White, T. J., Bruns, T., Lee, S. \& Taylor, J. (1990). Amplification and direct sequencing of fungal ribosomal RNA genes for phylogenetics. In PCR Protocols - a Guide to Methods and Applications, pp. 315-322. Edited by M. A. Innis, D. H. Gelfand, J. J. Sninsky \& T. J. White. San Diego, CA: Academic Press.

Yamada, K., Furukawa, T. \& Nakahara, T. (1970). Studies on the utilization of hydrocarbons by microorganisms. Part XVIII. Fermentative production of fumaric acid by Candida hydrocarbofumarica sp. nov. Agric Biol Chem 34, 670-675.

Yarrow, D. (1998). Methods for the isolation, maintenance and identification of yeasts. In The Yeasts, a Taxonomic Study, 4th edn, pp. 77-100. Edited by C. P. Kurtzman \& J. W. Fell. Amsterdam: Elsevier. 